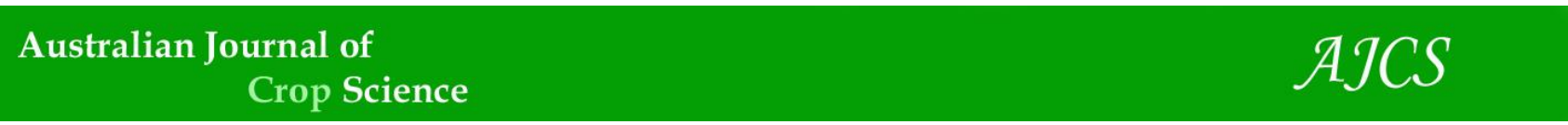

AJCS 11(10):1283-1289 (2017)

ISSN:1835-2707

doi: 10.21475/ajcs.17.11.10.pne577

\title{
Physiological responses of Urochloa ruziziensis inoculated with Azospirillum brasilense to severe drought and rehydration conditions
}

\author{
Lucas Guilherme Bulegon, Andre Gustavo Battistus, Vandeir Francisco Guimarães, Adriano Mitio \\ Inagaki, Luiz Claudio Offemann, Aline Kelly Pomini de Souza, Paulo Sergio Rabello de Oliveira
}

\author{
Agricultural Sciences Center. Parana Western State University - UNIOESTE. Pernambuco Street, 1777, Box 91, \\ Zip Code: 85960-000, Marechal Cândido Rondon - PR, Brazil
}

*Corresponding author: lucas_bulegon@yahoo.com.br

\begin{abstract}
This study evaluated the tolerance of $U$. ruziziensis under severe water stress conditions and its recovery when rehydrated, based in responses of relative leaf water content and gas exchange of the crop. The experiment was conducted in green house in Oxisol. The experimental design was a randomized block design, totaling five treatments, was represented by inoculation of $A$. brasilense strains AbV5 + AbV6, as follow: seed inoculation, foliar spray application, seed inoculation + foliar spray application, a non-inoculated control with water deficit treatment and a irrigated control without inoculation. Drought was imposed 45 days after sowing, after the vessel was irrigated until saturation of the substrate, by total removal of irrigation for six days, and evaluated three days after the resumption of water, evaluating gravimetric soil moisture, relative leaf water content and gas exchange. Soil moisture showed non variation to treatments non irrigated, but the relative leaf water content was lower in the control without water. The control and the treatment inoculated with $A$. brasilense in seeds exhibited lower rates of gas exchange. Recovery full of photosynthetic activity occurred three days after rehydration in all treatments. A. brasilense foliar sprayed is efficient to increase the tolerance of $U$. ruziziensis to water deficit and presented higher photosynthetic rates even under conditions of severe water deficit.
\end{abstract}

Keywords: Growth promoting bacteria, Forage grasses, Relative water content, Gas exchange.

Abbreviations: $A_{-} \mathrm{CO}_{2}$ net assimilation rate; $E_{-}$transpiration; $g_{s}$ stomatal conductance; $C_{-}$internal $\mathrm{CO}_{2}$ concentration; WUE efficiency of water use; iWUE _ intrinsic efficiency of water use; RWC _ relative water content.

\section{Introduction}

Water is of utmost importance in productive systems, and may represent about $90 \%$ fresh weight in plants (Azevedo et al., 2005). In major crops and pastures, this representation varies according to the developmental stages, ranging from $40 \%$ to $80 \%$ (Lima et al. 2012). Thus, the water deficit has a paramount impact in productivity systems.

Water deficit takes place when the plant transpiration rate exceeds the water uptake rate (Taiz and Zeiger 2013), leading to a physiological imbalance (Fioreze et al. 2013), triggering a series of reactions including the reduction of yields, grains and, in extreme cases, death of organs or the whole plant (Souza et al., 2014).

Grasses have peculiaritys that ensure resistance to drought, through morphological and physiological adaptations (Souza et al., 2014). In Brazil, pastures occupy most of the agricultural area, 173.2 millons hectares, and are responsible for maintaining the national herd. In this scenario, grasses, especially belonging to the genus Urochloa (syn. Brachiaria), represent about $80 \%$ of planted and/or reformed pastures (Lang et al., 2011). However, they are usually grown in soils of low fertility, in hilly areas and with limited mechanization procediments, making them dependent on natural rainfall, which are irregular (Maranhão et al., 2010) Thus, the effect of water deficit has been shown in several grasses, causing reduction of development, mainly because leaf expansion restriction, increasing leaf senescence and reducing the emergence of tillers. Mattos et al. (2005) reported the effect of drought on Urochloa pastures, reducing the growth of plants and dry matter. It was also demonstrated reduction in the development of Cynodon grown under drought conditions (Silva et al., 2005; Zhou et al., 2013).

Several studies investigated ways to increase tolerance to water deficit, primarily via genetical enhancement. Nevertheless, some studies indicate that the use of plant growth promoting bacteria increases the tolerance to water deficit under field conditions. Among these bacteria, Azospirillum brasilense has been widely used in many crops (Dartora et al., 2013; Quadros et al., 2014), aiming the production of plant hormones (Kuss et al., 2007), stimulation of root development and increase shoot dry matter (Dartora et al., 2013), intensifications in photosynthesis (Inagaki et al., 2015) and in crop yields (Quadros et al., 2014). Much of these results are associated with better use of productive resources, such as water.

Thus, as A. brasilense maximizes the use of productive resources, like water, it was aimed to evaluate the tolerance of Urochloa ruziziensis inoculated with Azospirillum brasilense under water stress conditions and rehydration, by means of the responses of relative leaf water content and gas exchange of the crop. 


\section{Results}

\section{Soil mosture and relative leaf water content (RWC)}

Was verified that only the irrigated control differed from the other treatments for the evaluations performed in moderated and severe water deficit (Fig. 1a). After the rehydration, no significant differences were observed among all the treatments.

There were not significant effects on relative leaf water content (RWC) in plants from different treatments on moderate water stress and rehydration (Fig.1b). Variations were obtained on severe water stress, where the control has less relative leaf water content $(49.47 \%)$ in relation to $A$. brasilense foliar spraying, while those theatments that received inoculation with $A$. brasilense in seed presented RWC of $62.37 \%$, foliar spray $65.05 \%$ and in seed + foliar spraying $62.96 \%$, representing a superiority of $26.07 \%$, $27.26 \%$ and $31.49 \%$ compared with the control, respectively (Fig. 1b). In turn, the plants kept under irrigation had a mean RWC of $93.79 \%$, promoting the highest average.

\section{Gas exchange}

The net assimilation rate of $\mathrm{CO}_{2}(A$ rate) under conditions of moderate water stress showed that the treatments kept in water restriction didn't differentiate between them. In severe water stress, control non irrigated and seed inoculation of $A$. brasilense had their rates of $A$ rate close to zero, promoted values of $0.015 \mu \mathrm{mol} \mathrm{CO} \mathrm{m}^{2} \mathrm{~s}^{-1}$ and $0.018 \mu \mathrm{mol} \mathrm{CO} \mathrm{m}^{2} \mathrm{~s}^{-1}$, respectively. On the other hand, the plants that received $A$. brasilense seed inoculation + foliar spraying maintained higher $A$ rates, followed by foliar spray of $A$. brasilense. In rehydration, seed inoculation promoted lower values than control and foliar spray of A. brasilense, however, all plants showed complete recovery of their photosynthetic rate (Fig.2a).

The internal $\mathrm{CO}_{2}$ concentration $(\mathrm{Ci})$ under moderate deficit conditions presented lower mean in control non irrigated and seed inoculation, the same treatments in severe deficit presented higher values of $\mathrm{Ci}$, similar to $\mathrm{C}_{3}$ plants, evidencing the deficiency in the $\mathrm{CO}_{2}$ net assimilation. The other treatments maintained in water deficit presented variations among themselves according to $A$ rates, while foliar spray of $A$. brasilense show greater $C i$ than seed inoculation + foliar spray $A$. brasilense. In rehydration, the values of $C i$ were normalized, and only seed inoculation + foliar spraying $A$. brasilense differed from the other non-irrigated treatments (Fig.2b).

For leaf transpiration $(E)$ and stomatal conductance $(g s)$ differences were obtained in moderate water deficit, linked to lower soil moisture (Fig.1a). At that moment the control non irrigated and seed inoculation of $A$. brasilense presented lower $E$, while the foliar spray of $A$. brasilense and seed inoculation + foliar spraying maintained greater $E$ and stomatal opening (Fig. 3a and 3b). These results suggest that the control non irrigated and seed inoculated of A. brasilense felt the lack of water in advance, they began the closing of the stomata to avoid greater losses of water in longer time. While the plants with foliar spray of A. brasilense, seed inoculation + foliar spraying $A$. brasilense and irrigated control kept their stomata open and increased transpiration rate.

In severe water stress, no significant differences were observed between treatments maintained in water deficit for $E$, being only the irrigated control superior. In rehydration for $g s$ and $E$, seed inoculation of $A$. brasilense presented lower values, differing only from control irrigated in $E$, and irrigated control, control non irrigated, and foliar spray of $A$. brasilense in $g s$.

In severe water stress, control non irrigated and seed inoculation $A$. brasilense had values of WUE and $i W U E$ near zero, while $A$. brasilense seed inoculated + foliar spraying elevated WUE and $i W U E$, surpassing the average of the irrigated control plants. Foliar spray of $A$. brasilense presented high averages, similar to irrigated control in WUE, and surpassed in $i W U E$ (Fig. 4a and 4b).

\section{Discussion}

The lowest RWC obtained in the control non irrigated plants is linked to the fact that these treatment promoted higher mass accumulation in the moment of the imposition of water deficit; in this moment, the control non irrigated plants had a shoot dry matter mass of $6.79 \mathrm{~g} \mathrm{plant}^{-1}$, while plants inoculated with $A$. brasilense in seed inoculation, on foliar spray application and $A$. brasilense seed inoculation + foliar spraying had 5.41, 4.59 and $4.95 \mathrm{~g} \mathrm{plant}^{-1}$, respectively.

As already mentioned, the water content in plants has no direct relationship with soil moisture (Pimentel et al., 2002), such condition occurred in the present study when the soil moisture gradualy decreased, the RWC showed an abruptly decreased (Fig. 1a and 1b).

Although the genus Urochloa is resistant to drought (Souza et al., 2014), these have a daily evapotranspiratory rate considered high, reaching $1.2 \mathrm{~mm}^{-1} \mathrm{y}^{-1}$ plant $^{-1}$ in sand soil, reaching $3.0 \mathrm{~mm} \mathrm{day}^{-1}$ plant $^{-1}$ for larger leaf area (Silva et al., 2014) and 2.6 day $^{-1}$ plant $^{-1}$ in the Brazilian cerrado soil (Meirelles et al., 2011). These values are close soybean (Casaroli et al., 2007) and bean (Fernandes et al., 2015), before the reproductive stages.

One of the causes for the sudden reduction in RWC is related to the adaptability of forage grasses: when it detect the lack of water by the increase in the content of abscisic acid (Taiz and Zeiger, 2013), initiating a process of leaf senescence in the lowest part of the canopy (Hu et al., 2010), it starts to prioritize water to the upper leaves. This fact occurred in compliance with this study, where the control non irrigated plants presented senescence of $1.20 \mathrm{~g} \mathrm{plant}^{-1}$ of leaves, while plants with foliar spray application of $A$. brasilense promoted $0.96 \mathrm{~g} \mathrm{plant}^{-1}$ of leaves. The mean was $0.84 \mathrm{~g} \mathrm{plant}^{-1}$ of leaves, suggesting that the foliar spray $A$. brasilense increases the plant tolerance to water deficit. However, under reduction of water in the substrate, the RWC quickly decreased and photosynthetic rate, being necessary to perform the rehydration.

This condition was also observed for Cynodon dactylon in shallow soil, where the cultivars possessing leaf senescence and increase abscicic acid resisted for until 20 days to the lack of water (Zhou et al., 2013). The same authors also report that $g s$ is reduced in the plant in different ways, and while the canopy presents stomata closed at the top they are partially open. Water restriction also influenced reducing the rate of leaf elongation, total length of leaf and number of green leaves and the development of forage grasses: Brachiaria purpurascens, Hermarthria altissima and Acroceras macrum, (Silva et al., 2005). In $U$. humidicola, $U$. decumbens and $U$. mutica are also reported on water deficit effects, including leaf senescence and reduction in leaf elongation rate (Mattos et al., 2005).

In other grasses there are reports that the RWC gradually decreases, as shown in wheat (Santos et al., 2012) and barley (Thameur et al., 2012), attributed to the improvement process 
Table 1. Chemical and physical characteristics of the soil used for the implementation of the experiment.

\begin{tabular}{|c|c|c|c|c|c|c|c|c|c|c|c|}
\hline $\mathrm{P}$ & O.M. & $\mathrm{pH} \mathrm{CaCl}{ }_{2}$ & $\mathrm{H}+\mathrm{Al}$ & $\mathrm{Al}^{+3}$ & $\mathrm{~K}^{+}$ & $\mathrm{Ca}^{+2}$ & $\mathrm{Mg}^{+2}$ & SB & CTC & $\mathrm{V}$ & $\mathrm{Al}$ \\
\hline $\mathrm{mg} \mathrm{dm}{ }^{3}$ & $\mathrm{~g} \mathrm{dm}^{3}$ & $\mathrm{~mol} \mathrm{~L}^{-1}$ & & \multicolumn{6}{|c|}{------------------ $\mathrm{cmol}_{\mathrm{c}} \mathrm{dm}^{-3}$--------------- } & \multicolumn{2}{|c|}{-----\%------ } \\
\hline 5,56 & 17,77 & 4,67 & 3,44 & 0,2 & 0,13 & 3,82 & 1,03 & 4,98 & 8,42 & 59,14 & 3,86 \\
\hline $\mathrm{Cu}$ & $\mathrm{Zn}$ & $\mathrm{Mn}$ & $\mathrm{Fe}$ & \multicolumn{3}{|c|}{ Argila } & & Silte & & \multicolumn{2}{|c|}{ Areia } \\
\hline \multicolumn{4}{|c|}{ 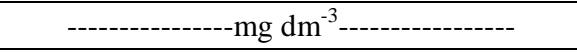 } & \multicolumn{8}{|c|}{ 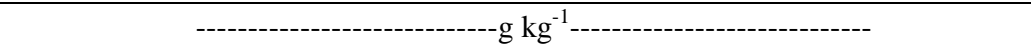 } \\
\hline 26,40 & 11,60 & 578,00 & 348,58 & \multicolumn{3}{|c|}{578,00} & \multicolumn{3}{|c|}{348,58} & \multicolumn{2}{|c|}{3,42} \\
\hline
\end{tabular}

O.M: Organic matter; $\mathrm{H}+\mathrm{Al}$ (potential acidity), $\mathrm{SB}$ (base sum), CTC (cation exchange capacity), $\mathrm{C}$ (organic carbon), $\mathrm{V} \%$ (base saturation).

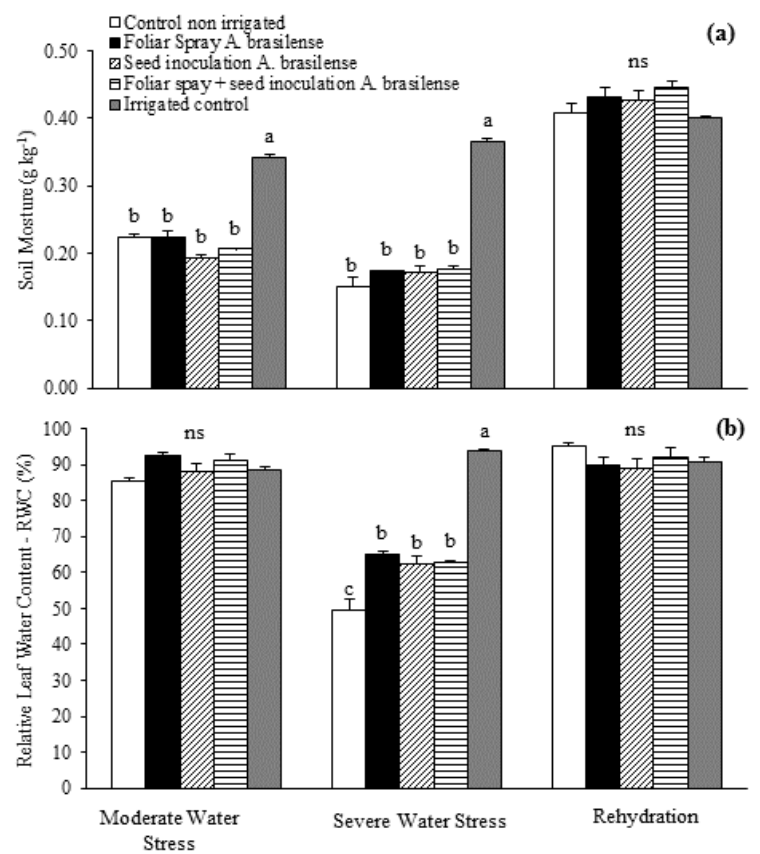

Fig 1. Soil Mosture (a) and Relative leaf water content (b) in U. ruziziensis under different inoculations with A. brasilense subjected to controlled drought. * Error bars indicate the SE. Moderate and Severe water stress assessed 4 and 6 days after withdrawal of water, respectively. Rehydration evaluated 3 days after water recovery. ns: not significant; Lowercase letters do not differ from each other by the Tukey test $\mathrm{p} \leq 0.05$.

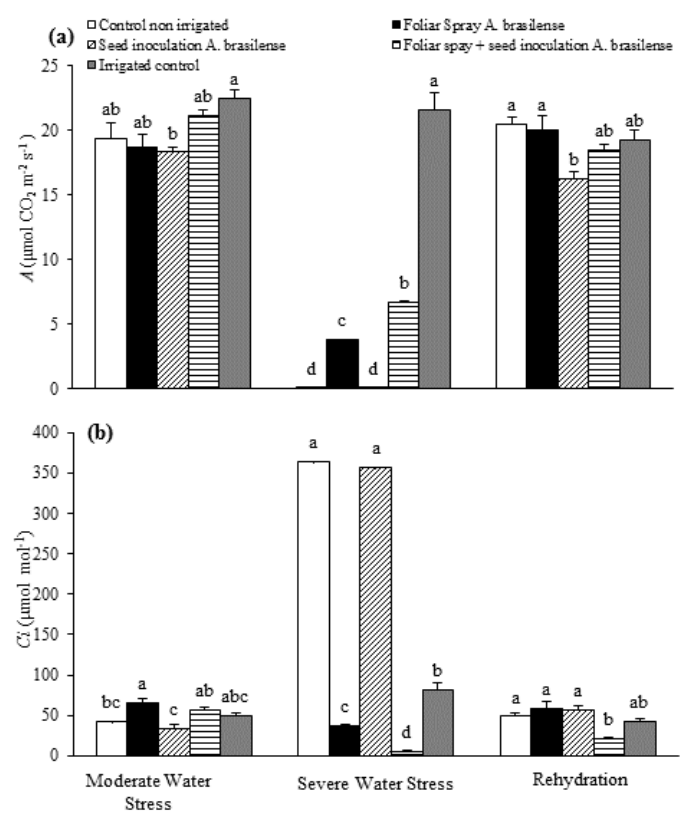

Fig 2. Net assimilation rate of $\mathrm{CO}_{2}-A$ (a) and internal $\mathrm{CO}_{2}$ concentration - $\mathrm{Ci}$ (b) U. ruziziensis subjected to different forms of inoculation of $A$. brasilense subjected to controlled drought. * Error bars indicate the SE. Moderate and Severe water stress assessed 4 and 6 days after withdrawal of water, respectively. Rehydration evaluated 3 days after water recovery. Lowercase letters do not differ from each other by the Tukey test $\mathrm{p} \leq 0.05$. 


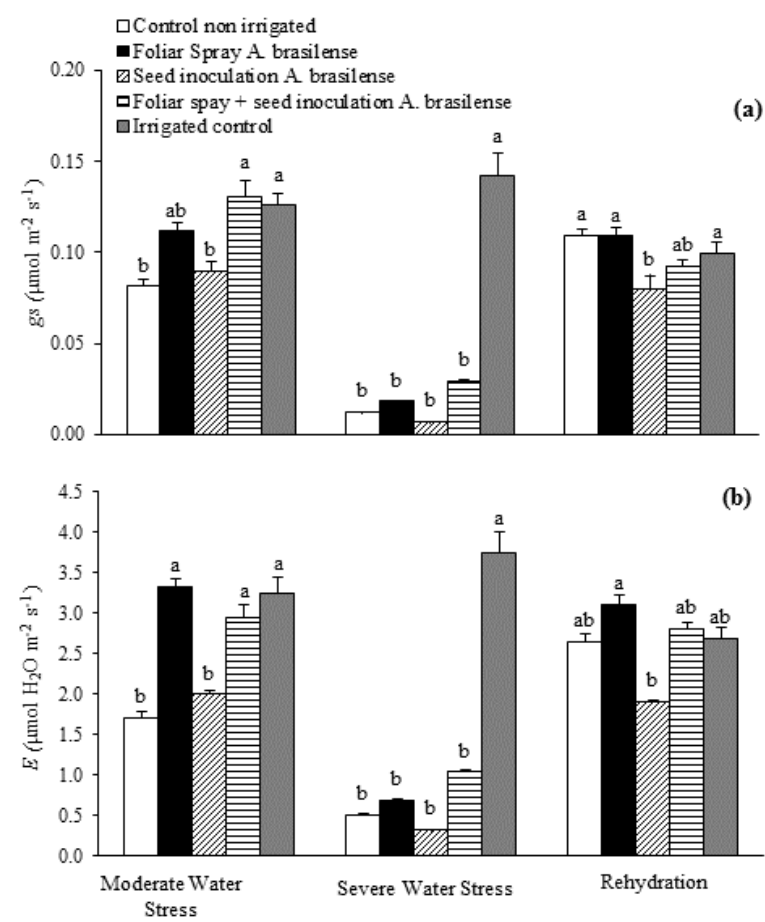

Fig 3. Stomatal conductance - $g s$ (a) and transpiration leaf - $E$ (b) U. ruziziensis subjected to different forms of inoculation of $A$. brasilense subjected to controlled drought.* Error bars indicate the SE. Moderate and Severe water stress assessed 4 and 6 days after withdrawal of water, respectively. Rehydration evaluated 3 days after water recovery. Lowercase letters do not differ from each other by the Tukey test $\mathrm{p} \leq 0.05$.

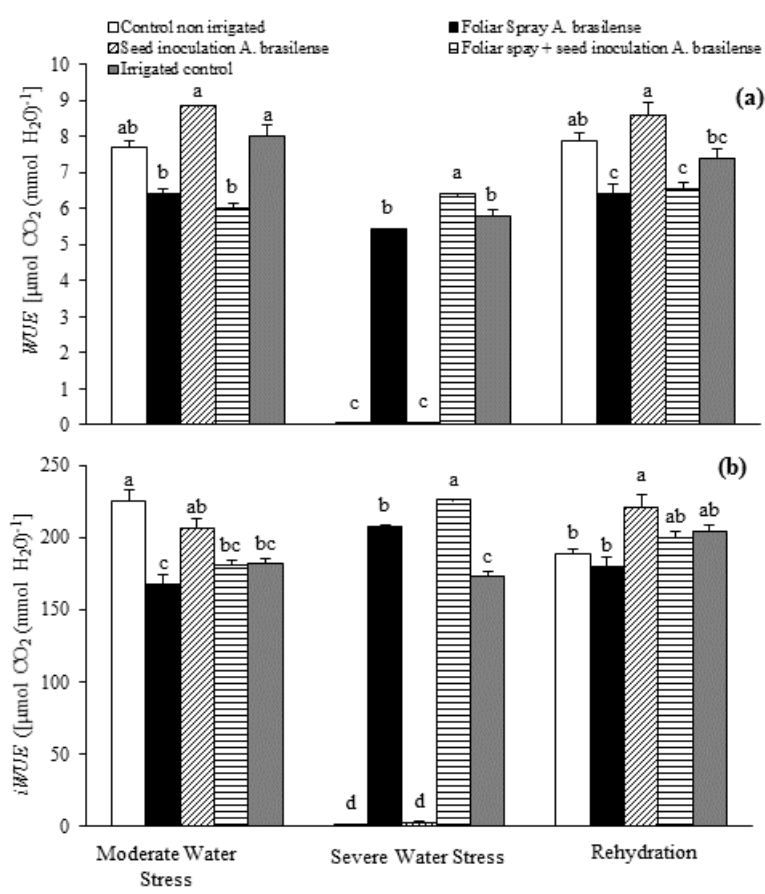

Fig 4. Efficient Water Use - WUE (a) Intrinsic and efficient use of water - $i W U E$ (b) $U$. ruziziensis subjected to different forms of inoculation of $A$. brasilense subjected to controlled drought. * Error bars indicate the SE. Moderate and Severe water stress assessed 4 and 6 days after withdrawal of water, respectively. Rehydration evaluated 3 days after water recovery. Lowercase letters do not differ from each other by the Tukey test $\mathrm{p} \leq 0.05$ 
that aims the maximum crop yield, not resulting in efficient process of leaf abortion in forage grasses. Among the adaptations of forage grasses to water deficit there are the physiological modifications, rapid responses not always linked to the evolutionary factor, but to adaptation to the environment where the plant develops (Sherrard et al. 2009; Souza et al. 2014), being the photosynthetic rate, stomatal conductance and transpiration, changes that firstly respond to water deficiency.Stomatal conductance presents variation more rapidly with the reduction of water available in the soil, as observed in several studies independent from the photosynthetic physiology of plants, reported for $\mathrm{C}_{3}$ (Santos et al., 2012; Yousfi et al., 2012; Fernandes et al., 2015) and $\mathrm{C}_{4}$ plants (Hu et al., 2010; (Mattos et al., 2005; Hu et al., 2010; Zhou et al., 2013). In the present study, this condition also occurs being observed the reduction of $g s$ (Fig.3a). These results show that control non irrigated plants and seed inoculated A. brasilense were earlier sensitive to lack of water and initiated the stomata closure process to avoid further loss of water. On the other hand, plants inoculated foliar spray A. brasilense and control non irrigated, hold their stomata opening and resulting in greater transpiration.

The $A$ rates values, found before the fourth day are consistent with those described in the literature for forages, since values between 15 and $20 \mu \mathrm{mol} \mathrm{m} \mathrm{m}^{-1}$ are found for Urochloa (Mattos et al., 2005). The drop of $A$ rates obtained in the severe water (Fig. 2a) is associated with the low water availability, since this is an initial electron acceptor for the photosystem II. There is also an increase in the abscisic acid content produced in the root by low water availability that is transported to the aerial part (Taiz and Zeiger, 2013).

The increase in $C i$ points to two conditions related to $A$ rates, being beneficial or undesirable to the plant. Thus, when the maintainance of the photosynthesis is observed, the increase in $\mathrm{Ci}$ is desirable, showing that the photosynthetic apparatus is functional. However, when the photosynthesis is near zero, as the obtained for the control non irrigated and the seed inoculation with A. brasilense, it represents a deficiency in the photosynthetic apparatus of the plant, because with the stomatal closure caused by the low water availability, the $\mathrm{CO}_{2}$ content in the substomatal chamber increases. However, the Rubisco is not fully activated due to the lack of water, thus the $\mathrm{CO}_{2}$ is not carboxylated and incorporated into the Krebs cycle, therefore increasing the $C i$.

The evaluations of $W U E$ and $i W U E$ were performed to confirm the direct relationships between $A$ rates, $g s$ and $E$, showing behavior similar to those found for each variable individually. Even under conditions of water deficit, WUE and $i W U E$ can remain high, which was found in treatments of foliar spraying of $A$. brasilense and A. brasilense seed inoculation + foliar spraying (Fig. $4 \mathrm{a}$ and $4 \mathrm{~b}$ ). This fact was also registered in soybean crops (Hossain et al., 2014), which represents resistence of plant to water deficit. The WUE and $i W U E$ were also used to differentiate cultivars of Cynodon spp. (Zhou et al., 2013) and barley (Thameur et al., 2012), resistant and susceptible to drought. In this sense, we can consider that the foliar application of A. brasilense makes the plant more resitant to water deficit. As mentioned above, when rehydration occurs, the plant rapidly recovers its content of water in the leaves. However, the photosynthetic process does not recover at the same rate (Slama et al., 2015). This is related to the abscisic acid level, which acted limiting photosynthesis. During the recovery, the plant can respond by two ways, gradually increasing gas exchange until restoration, which is desirable from the point of view of energy cost and use of water, which ocurred in the control and inoculation in the seed. Or even, occuring exchanges in an unregulated form, with large increases and subsequent reductions, condition managed by the hormonal lack of control of the abscisic acid that still acts in the plant, as in the treatments that received foliar spraying A. brasilense. The classic study of Mansfield and Davies (1985) evidenced that the effect of water deficit can remain in the plant for a long period, what they called "residual effect of water deficit", interfering in crops gas exchanges, being represented mainly by the restriction in the $\mathrm{CO}_{2}$ uptake. Thus, when we evaluate $\mathrm{Ci}$ (Fig. 2b), could be observed that it recover his concentration similarly to the initial condition, indicating that $U$. ruziziensis, after three days from the rehydration, functioning of the photosynthetic apparatus similar to initial condition. Unlike the results of this study, Mattos et al. (2005), also under greenhouse conditions, mentioned that even after nine days of rehydration, $U$. brizantha and $U$. mutica were not able to retake gas exchanges at the original levels observed before the introduction of stress.

\section{Materials and methods}

\section{Plant materials}

For the development of the study we used pelletized seeds of Urochloa ruziziensis, with a cultural value of $60 \%$, being a grass of tropical climate, with average height of $1.5 \mathrm{~m}$, a habit of growing decaceous rook and high capacity of dry mass.

\section{Experimental design and Treatments}

The work was conducted under a randomized block design, consisting of five treatments and four replications. The treatments were represented as follows: Irrigated control without A. brasilense inoculation; Non-irrigated control without inoculation; A. brasilense seed inoculation without irrigation; A. brasilense foliar spraying without irrigation; $A$. brasilense seed inoculation + folair spraying without irrigation.

\section{Conduction of experiment}

The experiment was conducted in pots with nominal capacity of 8.7 liters, which contained soil from the Oxisol A horizon (Table 1), with a natural population of diazotrophs at $4 \times 10^{5}$ CFU g ${ }^{-1}$ soil (Dödereiner et al., 1995).

The application of $A$. brasilense strain AbV5 + AbV6 on seeds of $U$. ruziziensis was performed at a dose of $1 \mathrm{~mL}$ inoculum $\left(2 \times 10^{8} \mathrm{CFU} \mathrm{mL} \mathrm{m}^{-1}\right)$ for 1000 seeds, which were homogenised and kept in the shadow for about 30 minutes before sowing. After sowing, pots were kept under field conditions, with daily replenishment of water. Two plants were kept per pot, without nutrient application throughout the experiment. The A. brasilense foliar spraying on was carried out when the plants were at the early tillering, approximately 20 days after sowing, with a dose of $300 \mathrm{~mL} \mathrm{ha}^{-1}$ of inoculum and spray volume of $300 \mathrm{~L} \mathrm{ha}^{-1}$, with the aid of a $\mathrm{CO}_{2}$ sprayer with constant pressure $40 \mathrm{kgf} \mathrm{cm}^{-2}$.

At 45 days after sowing (DAS) was imposed water deficit. All pots were watered before to start drought, to reaching the field condition. Treatments of water deficit had their irrigation suspended, and kept under water restriction for six days when the plants, in at least one treatment, reached the photosynthetic rate near zero, after this all out rehydrated (Supplementary Fig 1, 2, 3 and 4). The plants were rehydrated by watering the pots until they reached the field capacity, similar to initial moisture content of the experiment 
(Supplementary Fig. 1a). The evalution perform in the moderate water stress (plants suffer from water deficit during the day and recover slowly at night), in the severe water stress (plants suffer from water deficit during the day and do not fully recover overnight) and rehydration was evaluated until plants showed photosynthetic rate close to the initial condition, 3 days after irrigation (Supplementary Fig 2, 3 and 4). In the treatment without water deficit (control irrigated), pots were periodically irrigated with adequate water supply, based in gravimetric moisture initial (Fig 1), replacing water to maintain the gravimetric moisture level of the previous day. Was determined daily, at predawn, a sample of the soil profile contained in each pot was taken, weighed at the time of collection (U1), and dried in a forced air circulation oven at $105{ }^{\circ} \mathrm{C}$ for $24 \mathrm{~h}$, and then weighed again (U2). The gravimetric moisture was obtained by: $\mathrm{UG}\left(\mathrm{kg} \mathrm{kg}^{-1}\right)=\mathrm{U} 1-$ $\mathrm{U} 2 / \mathrm{U} 2$.

\section{Determination of relative leaf water content (RWC)}

The determination of RWC was performed daily at predawn by collecting $1.5 \mathrm{~cm}^{2}$ leaf samples located in the middle of the plant. This, which were weighed at the time of collection, after they were taken for hydration for at $25{ }^{\circ} \mathrm{C}$ for six hours, to obtain turgid fresh weight and subsequently taken to a forced air circulation oven at $65^{\circ} \mathrm{C}$ until constant weight to determine dry matter (DM) (Slavik, 1974).

\section{Gas exchange}

To examine the stress imposed about gas exchange, were determined daily using the equipment IRGA LI-6400XT (Infra Red Gas Analyzer) (Licor Inc. Lincoln, NE). Readings were taken in the morning between $09 \mathrm{~h} 00 \mathrm{~min}$ and $11 \mathrm{~h} 00 \mathrm{~min}$ using $\mathrm{CO}_{2}$ ambiente content of $380 \mu \mathrm{mol} \mathrm{mol}{ }^{-1}$, in fully developed leaves, photosynthetically active and intact, located in the middle third.

We also determined net $\mathrm{CO}_{2}$ assimilation rate $(A)$, leaf transpiration rate $(E)$; stomatal conductance $(g s)$, internal $\mathrm{CO}_{2}$ concentration $(\mathrm{Ci})$, and the following ratios: $W U E=$ $A / E, i W U E=A / g s$ (Zhang et al., 2001), wherein $W U E$ is the efficiency of water use, $i W U E$ is the intrinsic efficiency of water use.

\section{Statistical analysis}

Statistical analysis was performed by F-test, and the means were compared by Tukey's test at $5 \%$ probability, using the software SISVAR.

\section{Conclusion}

A. brasilense foliar spraying and A. brasilense seed inoculation + foliar spraying is efficient to increase the tolerance of $U$. ruziziensis to water deficit. The plants that received A. brasilense on foliar spray, isolated or combined with seed inoculation, presented higher photosynthetic rates even under conditions of severe water deficit.

\section{Acknowledgments}

The authors thank the Coordination for the Improvement of Higher Education Personnel (CAPES-Brazil), the Araucaria Foundation that supports the scientific and technological development in the State of Paraná, affiliated with the State Secretariat of Science, Technology and Higher Education SETI, CAPES / PNPD, the INCT-FBN for the financial support and CNPq for the productivity scholarship granted to the researcher Dr. Vandeir Francisco Guimarães.

\section{References}

Azevedo BM, Bastos FGC, Viana TVA, Rêgo JL, D’Ávila JHT (2005) Efeitos de níveis de irrigação na cultura da melancia. Rev Cien Aagro. 36:9-15.

Casaroli D, Fagan EB, Simon J, Medeiros SP, Manfron PA, Neto DD, Lier QJV, Muller L, Martin TN (2007) Radiação solar e aspectos fisiológicos na cultura de soja - uma revisão. Revista FZVA. 14:102-120.

Dartora J, Guimarães VF, Marini D, Sander G (2013) Adubação nitrogenada associada à inoculação com Azospirillum brasilense e Herbaspirillum seropedicae na cultura do milho. Rev Bras Eng Agíc Ambient. 17:10231029.

Dödereiner J, Baldani VLD, Baldani JI (1995) Como isolar e identificar bactérias diazotróficas de plantas não leguminosa.

Fernandes FBP, Lacerda CF, Andrade EM, Neves ALR, Sousa CHC (2015) Effect of soil management on water deficit, gas exchange and cowpea yield in the semi-arid region. Rev Cien Agro. 46: 506-515.

Fioreze SL, Rodrigues JD, Carneiro JPC, Silva ADA, Lima MB (2013) Fisiologia e produção da soja tratada com cinetina e cálcio sob deficit hídrico e sombreamento. Pes Agropec Bras. 48:1432-1439.

Hossain MM, Liu X, Qi X, Lam H-M, Zhang J (2014) Differences between soybean genotypes in physiological response to sequential soil drying and rewetting. The Crop Journal. 15:1-15.

Hu L, Wang Z, Huang B (2010) Diffusion limitations and metabolic factors associated with inhibition and recovery of photosynthesis from drought stress in a $\mathrm{C}_{3}$ perennial grass species. Physiol Plantarum. 139:93-106.

Kaschuk G, Kuyper TW, Leffelaar PA., Hungria M, Giller KE (2009) Are the rates of photosynthesis stimulated by the carbon sink strength of rhizobial and arbuscular mycorrhizal symbioses? Soil Biol Biochem. 41:1233-1244.

Kuss AV, Kuss VV, Lovato T, Flôres ML (2007) Fixação de nitrogênio e produção de ácido indolacético in vitro por bactérias diazotróficas endofíticas. Pes Agropec Bras. 42:1459-1465.

Lang CR, Pelissari A, Moraes A, Sulc RM, Carvalho PCF, Lopes ÉCP (2011) Integração lavoura - pecuária: eficiência de uso do nitrogênio na cultura do milho. Scientia Agraria. 12:53-60.

Lima MDB, Carrijo MS, Costa KAP, Dan HA, Simon GA (2012) Water use efficiency in alfafa production under different irrigation managements. Brazilian Journal of Irrigation and Drainage. 17:448-455.

Mansfield TA, Davies WJ (1985) Mechanisms for leaf control of gas exchange. Bioscience. 35:158-164.

Maranhão CMA, Bonomo P, Pires AJV, Costa ACPR, Martins GCF, Cardoso EO (2010) Características produtivas do capim-braquiária submetido a intervalos de cortes e adubação nitrogenada durante três estações. Acta Sci Anim. sci. 32:375-384.

Mattos JLS, Gomide JA, Huaman CAM (2005) Effect of water deficit on the growth of Brachiaria species in greenhouse. Rev Bras Zootec. 34:746-754.

Meirelles ML, Franco AC, Farias SEM, Bracho R (2011) Evapotranspiration and plant atmospheric coupling in a Brachiaria brizantha pasture in the Brazilian savannah region. Grass Forage Sci. 66:206-213. 
Pimentel C, Sarr B, Diouf O, Abboud ACS, Roy-macauley H (2002) Tolerância protoplasmatica foliar à seca, em dois genótipos de caupi cultivados em campo. Revista da Universidade Rural. 22:7-14.

Quadros PD, Roesch LFW, Silva PRF, Vieira VM, Roehrs DD, Oliveira Camargo FA (2014) Desempenho agronômico a campo de híbridos de milho inoculados com Azospirillum. Rev Ceres. 61:209-218.

Santos D, Guimarães VF, Klein J, Fioreze SL, Macedo Jr EK (2012) Cultivares de trigo submetidas a déficit hídrico no início do florescimento, em casa de vegetação. Rev Bras Eng Agíc Ambient. 16:836-842.

Sherrard ME, Maherali H, Latta RG (2009) Water stress alters the genetic architecture of functional traits associated with drought adaptation in avena barbata. Evolution. 63:702-715.

Silva RAB, Lima JRDS, Antonino ACD, Gondim PSDS, Souza ES, Barros G (2014) Balanço hídrico em neossolo regolítico cultivado com braquiária (Brachiaria decumbens Stapf). Rev Bras Cienc Solo. 38:147-157.

Silva MMP, Vasquez HM, Bressan-Smith RE, Silva JFC, Erbesdobler ED, Andrade Jr PSC (2005) Respostas morfogênicas de gramíneas forrageiras tropicais sob diferentes condições hídricas do solo. Rev Bras Zootec. 34:1493-1504.
Slama I, M'Rabet R, Ksouri R, Talbi O, Debez A, Abdelly C (2015) Water deficit stress applied only or combined with salinity affects physiological parameters and antioxidant capacity in Sesuvium portulacastrum. Flora. 213:69-76.

Slavik B (1974) Methods of studying plant water relations.

Souza FHD, Matta FP, Fávero AP (2014) Construção de ideótipos de gramíneas para usos diversos. Embrapa. Brasilia.

Taiz L, Zeiger E (2013) Fisiologia Vegetal. Artemed. Porto Alegre.

Thameur A, Lachiheb B, Ferchichi A (2012) Drought effect on growth, gas exchange and yield, in two strains of local barley Ardhaoui, under water deficit conditions in southern Tunisia. J Environ Manage. 113:495-500.

Yousfi N, Slama I, Abdelly C (2012) Phenology, leaf gas exchange, growth, and seed yield in contrasting Medicago truncatula and Medicago laciniata populations during prolonged water deficit and recovery. Botany. 90:79-91.

Zhang S, Li Q, Ma K, Chen L (2001) Temperature dependent gas exchange and stomatal/non-stomatal limitation to $\mathrm{CO}_{2}$ assimilation of Quercus liaotungensis under midday high irradiance. Photosynthetica. 39:383-388.

Zhou Y, Lambrides CJ, Fukai S (2013) Drought resistance of bermudagrass (Cynodon spp.) ecotypes collected from different climatic zones. Environ Exp Bot. 85:22-29. 